\title{
Physicochemical properties and antioxidant activities of spray-dried powder from safflower extract
}

\author{
Mi Jeong Lim, Joo-Heon Hong* \\ Department of Food Science and Technology, Deagu Catholic University, Daegu 38430, Korea
}

\section{홍화 추출물을 이용한 분무건조 분말의 물리화학적 품질 특성 및 항산화 활성 \\ 임미정 · 홍주헌* \\ 대구가톨릭대학교 식품공학과}

\begin{abstract}
This study was conducted to examine the physicochemical properties and antioxidant activities of spray-dried (SD) powders using different cyclodextrin and maltodextrin ratios of safflower extract. The extraction yield of SD powders was $68.02-87.68 \%$. The moisture content of $10 \%$ maltodextrin spray-dried powder (MD10) was higher than that of the other powders investigated. The color values $L$, a, and $b$ of SD powders were higher than those of freeze-dried (FD) powder. The particle size increased as the wall material increased. Scanning electron microscope (SEM) images showed that the SD powders were spherical. The water absorption index and water solubility index of the SD powders were $0.55-0.61$ and $90.67-96.67 \%$, respectively. The decomposition temperature of SD powders was $283^{\circ} \mathrm{C}$. The concentration of the phenolic compounds of MD10 $(1.07 \mathrm{~g} / 100 \mathrm{~g})$ was higher than those of the SD powders (0.20-1.06 $\mathrm{g} / 100 \mathrm{~g}$ ). The DPPH and ABTS radical scavenging activities of MD10 at $1,000 \mu \mathrm{g} / \mathrm{mL}$ were 13.40 and $24.10 \%$, respectively. The FRAP activity of SD powders from 100 to $1,000 \mu \mathrm{g} / \mathrm{mL}$ was 16.70 to $191.57 \mu \mathrm{M}$, respectively. The superoxide radical scavenging activity of MD10 (85.37\%) was superior to those of other SD powders. This study suggests that SD powders with safflower extract have enhanced storage stability and may be useful as functional processing materials.
\end{abstract}

Key words : Carthamus tinctorius L., maltodextrin $10 \%$ powder, phenolics, antioxidant activity, storage stability

서 론

생체 내에서는 에너지 생산을 위해 산화과정 중 상당량의 활성산소들이 생성되며, 활성산소가 순간적으로 다량 발생되 거나 만성적 상태가 유지되면 세포 구성성분과 강하게 반응 하여 세포와 조직에 손상을 가하고 지속적일 시 DNA 변성, 지질 산화, 단백질 분해 등을 초래하여 세포의 기능장애, 암을 비롯한 뇌졸중, 파킨슨병과 뇌질환, 동맥경화, 심장질환, 자가 면역질환, 염증 노화 등의 각종 질병을 일으키는 것으로 알려
져 있다(Lee 등, 2011; You와 Moon, 2016). 현재 일반적으로 사용되고 있는 항산화제는 인공합성 항산화제인 butylated hydroxyanisole(BHA)과 butylated hydroxytoluene(BHT)으 로 다른 항산화제에 비해 가열 가공식품에 효력 이행성이 높 다고 알려져 있으나, 장시간 복용할 경우 간 손상 및 발암물 질과 같은 부작용을 동반할 수 있다고 보고되고 있다(Chipiti 등, 2013; Yoon과 Kim, 1988). 이렇게 합성 항산화제의 안정 성 문제가 제기되고 있어 효능이 우수하고 안전성 면에서 입 증된 천연 항산화제를 개발하기 위한 연구들이 수행되고 있

*Corresponding author. E-mail : jhhong@cu.ac.kr, Phone : +82-53-850-3218, Fax : +82-53-850-3218

Received 14 September 2020; Revised 01 December 2020; Accepted 04 January 2021.

Copyright (c) The Korean Society of Food Preservation.

This is an Open Access article distributed under the terms of the Creative Commons Attribution Non-Commercial License (http://creativecommons.org/licenses/by-nc/4.0) which permits unrestricted non-commercial use, distribution, and reproduction in any medium, provided the original work is properly cited. 
다(Kim, 2004).

홍화는 국화과에 속하는 일년생 초목으로 원산지는 아프 카니스탄 산악지대 또는 이집트 및 에티오피아이며, 한국, 중 국, 일본, 인도 등에서 재배되고 있다(Kim 등, 2008). 홍화는 식물의 크기가 $1 \mathrm{~m}$ 정도로 잎은 어긋나며, 넓은 버들잎ㅁㅇㅑㅑㅇ 의 꽃싼잎이 돌려나며, 7-8월에 황색의 꽃이 피고 엉겅퀴같 이 생겼으나 붉은빛이 도는 노란색으로 가지 끝에 1 개의 꽃 이 개화한다(Lee, 1980). 홍화 꽃은 수용성 색소와 불용성의 적색색소를 함유하고 있어 예로부터 염료로 사용되어 왔으며, 성분으로는 C-glucosylqunochalcone 계열물질과 kaempferol, quercetin 등의 flavonoid 계열의 물질들이 분리됨으로 알려 져 있다(Kim 등, 1996). 본초강목에서는 통증을 제거, 혈액순 환을 원활하게 해주며, 혈행장애, 통경액, 맹증, 갱년기 장해 등의 처방제로 사용되고, 완화작용, 발한작용, 하혈작용이 있 다고 알려져 있다(Kang, 2001; Park, 2015). 또한 홍화는 강 력한 항산화 활성을 가지며 항염증 효과, 항응혈 효과, 골질 환개선 효과, 항암 효과를 가짐으로 보고되었다(Jung 등, 2019; Kutsuna 등, 1988). 이와 같이 생리학적으로 우수하지 만 섭취의 이용이 어려운 홍화의 활용과 저장성 증진을 위한 제품형태 및 가공방법이 필요한 실정이다(Park 등, 2017).

분무건조는 고온의 chamber 안으로 시료를 분사시켜 액상 형태의 물질을 미세한 고체입자형태로 연속적으로 변환시키 는 건조기술로 동결건조와 함께 산업에서 가장 널리 사용되 며(Tan 등, 2005), 빠른 건조속도, 낮은 에너지 소비로 의약 품, 공업재료, 향료 및 식품 분야에 응용될 수 있다(Lee 등, 1997; Park 등, 2017). 식품 분야에서는 식품 첨가물 또는 식품 유용물질을 인위적으로 캡슐화함으로써 식품소재의 산화 방지 및 보전성 향상, 변화하기 쉬운 식품소재의 안정화, 불필요한 냄새의 차단, 액상식품의 고형화 가능, 제조공정의 개선 및 물 질 향상 등의 장점을 가지고 있다(Shin, 2009). 분무건조 시 사 용되는 피복물질은 주로 starch, arabic gum, cyclodextrin, maltodextrin, cellulose 등 다양한 다당류가 전통적으로 이용 되고 있다(Dzondo-Gadet 등, 2005). 피복물질 중 cyclodextrin 은 소수성 내부로 외부적인 요인으로 보호받을 수 있으며, 산 소, 열, 빛에 대한 안정성이 높고 가격도 저렴하여 식품, 제 약, 화장품산업에 응용되고 있다(Del Valle, 2004). Maltodextrin은 분무건조 중 식품의 영양성분, 색, 향미 유지에 효 과적이고 산화투과도를 감소시키는 특성이 있어 항산화제 없 이도 안정성이 우수하며 비용적인 측면에서도 유리하여 산업 현장에서 많이 적용되고 있다(Rodriguez 등, 2005).

따라서 본 연구에서는 다양한 생리활성을 가진 천연 약용 물질인 홍화의 이용가치를 향상시키기 위해 홍화 추출물에 cyclodextrin과 maltodextrin을 부형제로 첨가하여 분무건조 분말을 제조하였으며, 분말의 물리화학적 품질 특성과 항산
화 활성을 조사하여 기능성 식품 가공용 소재로의 활용 가능 성을 확인하고자 하였다.

\section{재료 및 방법}

\section{실험재료}

본 실험에 사용된 건조 홍화(Carthamus tinctorius L., 국 내산)는 농업회사법인 (주)다모(Uiseong, Korea)에서 제공받 아 상온에서 보관하면서 분쇄기(FM-909, Hanil Co., Sejong, Korea)로 분쇄 후 표준망체(60 mesh, Chung Gye Sang Cong $\mathrm{Sa}, \mathrm{Seoul}, \mathrm{Korea})$ 를 통과한 분말을 추출용 시료로 사용하였 다.

\section{추출물 제조}

홍화 추출물 제조는 $30 \mathrm{~g}$ 의 홍화 분말에 $80 \%$ 에탄올을 고 형분 대비 10 배 첨가하여 $80^{\circ} \mathrm{C}$ 에서 4 시간 동안 환류냉각추출 기(CA-1112, Eyela Co., Tokyo, Japan)를 이용하여 2회 반복 추출하였다. 각각의 추출물은 여과지(No.4, Whatman International Ltd., Leicestershire, England)를 사용하여 불순 물을 제거하고 여과된 추출물은 감압농축기 $(\mathrm{N}-1 \mathrm{~N}$, Eyela Co., Tokyo, Japan)로 농축한 다음, 동결건조기(Free Zone 2.5, Labconco Co., Kansas, MO, USA)를 이용하여 건조 후 $-70^{\circ} \mathrm{C}$ 이하의 암소에서 보관하며 분석용 시료로 사용하였다.

\section{분무건조 분말 제조}

홍화 $80 \%$ 에탄올 추출농축액에 cyclodextrin(Cydex-s, Daesang Co., Gunsan, Korea)을 각각 10\%(CD10), $20 \%$ (CD20), maltodextrin을 각각 10\%(MD10), 20\%(MD20) 및 cyclodextrin과 maltodextrin( $\mathrm{DE}=14$, Daesang Co.)의 동량 혼합물을 $10 \%(\mathrm{CDMD} 10), 20 \%(\mathrm{CDMD} 20)$ 비율로 첨가하여 $20{ }^{\circ} \mathrm{Brix}$ 의 농도로 조정한 다음 고압균질기(HG-15D, Daihan scientific Co., Wonju, Korea)를 이용하여 6,000 rpm에서 30 분간 균질화한 후 분무건조기(KL-8, Seogang, Engineering Co., Ltd., Cheonan, Korea)를 사용하여 분말을 제조하였다. 이때 분무건조 조건은 주입온도 $150^{\circ} \mathrm{C}$, 방출온도 $100^{\circ} \mathrm{C}$, 분 무속도 $16,000 \mathrm{rpm}$ 및 시료공급속도는 $14 \mathrm{~mL} / \mathrm{min}$ 로 설정하 였다. 제조된 분말은 $-70^{\circ} \mathrm{C}$ 이하의 암소에서 보관하면서 분석 용 시료로 사용하였다.

\section{수율 및 수분함량 측정}

수율은 홍화 추출물을 분무건조한 다음, 건물의 중량을 구 하여 시료 조제에 사용한 원료건물량에 대한 백분율로 나타내 었다. 수분함량은 분말 $0.5 \mathrm{~g}$ 을 petridish에 담아 적외선 수분 측정기(MB-45, Moisture analyzer, Inc., Ohaus, Parsippany, 
$\mathrm{NJ}, \mathrm{USA}$ )를 이용하여 $105^{\circ} \mathrm{C}$ 에서 분말의 수분함량이 항량에 도달할 때까지 건조하여 측정하였다.

\section{색도, 입자크기 및 입자표면구조 측정}

색도는 petridish에 시료를 $6 \mathrm{~g}$ 씩 담아 표준색도( $\mathrm{Y}=86.6$, $\mathrm{x}=0.3160, \mathrm{y}=0.3214)$ 로 보정된 색도계(Chromameter CR200, Minolta Co., Osaka, Japan)를 사용하여 L값(Lightness, 명 도), a값(redness-greenness, 적색도), b값(yellow-bluness, 황 색도)을 3 회 반복측정하여 평균값과 표준편차를 나타내었다.

입자크기는 각각의 분말을 isopropyl alcohol에 분산시켜 particle size analyzer(LS-13-320, Beckman coulter, Fullerton, $\mathrm{CA}, \mathrm{USA}$ )로 측정하였다. 입자표면구조는 시료에 gold ion coating을 하고 주사형 전자현미경(S-4800, Hatachi HighTechnologies Co., Tokyo, Japan)을 이용하여 $3.0 \mathrm{kV}$ 에서 500 배 배율로 관찰하였다.

\section{수분흡수지수 및 수분용해지수 측정}

수분흡수지수 및 수분용해지수는 Phillips 등(1988)의 방법 에 따라 분말 $0.5 \mathrm{~g}$ 에 증류수 $20 \mathrm{~mL}$ 를 혼합하여 $3,000 \mathrm{rpm}$ 으로 설정된 원심분리기(VS-6000 CFN, Chison Scien-tific Co., Bucheon, Korea)를 사용하여 20분 동안 원심분리한 다 음 상등액을 제외한 침전물의 무게를 평량하여 건조시료 $\mathrm{g}$ 당 흡수된 수분의 함량을 수분흡수지수로 표시하였고, 수분 용해지수는 수분흡수지수 측정 시 회수한 상등액을 미리 무 게를 구한 수기에 분리하여 $105^{\circ} \mathrm{C}$ 로 조절한 강제순환 건조기 (OF-22GW, Jeio tech Co., Ltd., Seoul, Korea)에서 4시간 동 안 건조시킨 후 얻은 고형분의 함량을 건조시료에 대한 백분 율로 나타내었다.

Water absorption index $(\mathrm{WAI})=$

$$
\text { ( } \frac{\text { wet sediment weight }}{\text { dry sample weight }} \text { ) }
$$

Water solubility index(WSI, \%) =

$$
\left(\frac{\text { dry supernatant weight }}{\text { dry sample weight }}\right) \times 100
$$

\section{$\mathrm{TGA}$ 분석}

열분해 온도를 조사하기 위해 thermogravimetric analyzer (Q600, TA instruments, Twin Lakes, WI, USA)를 이용하여 온도에 따른 무게감량을 측정하였다. 이때 가열속도는 $10^{\circ} \mathrm{C}$ $/ \mathrm{min}$, 온도는 $25-700^{\circ} \mathrm{C}$ 까지 질소기류 $(500 \mathrm{~mL} / \mathrm{min})$ 하에서 측정하였다.

\section{페놀화합물 함량 분석}

페놀화합물을 측정하기 위해 high performance liquid chromatography(HPLC)를 이용하여 분석하였으며, 시료는 증류수에 희석하여 $1,000 \mu \mathrm{g} / \mathrm{mL}$ 농도로 제조한 다음 0.45 $\mu \mathrm{m}$ syringe filter(DISMIC-25AS, Advantec Ltd., Tokyo, Japan)로 여과하여 분석용 시료로 사용하였다. Alliance HPLC system 2695(Waters Co., Miliford, MA, USA)를 이 용하여 photodiode array detector 2996(Waters Co.)으로 분 석하였다. 분석용 칼럼은 Hypersil GOLD HILIC(particle size $5 \mu \mathrm{m}, 4.6 \times 250 \mathrm{~mm}$, Thermo scientific Co., Waltham $\mathrm{MA}, \mathrm{USA}$ )를 사용하였으며, 칼럼과 시료 온도는 $25^{\circ} \mathrm{C}$, 유속 은 $1.0 \mathrm{~mL} / \mathrm{min}$ 로 하여 시료를 $10 \mu \mathrm{L}$ 씩 주입하여 측정하였 다. 분석용 용매는 water:formic acid(99.5:0.5, v/v; mobile phase A) 및 100\% methanol(mobile phase B)을 사용하여 mobile phase $\mathrm{A}$ 를 기준으로 $60 \%$ ( 0 분), $40 \%$ (20분), $60 \%(21$ 분) 및 $60 \%$ (30분)로 하여 gradient로 분석하였다. 페놀화합물 함량은 표준물질을 이용하여 표준곡선으로 정량하였고, 표준 물질은 p-coumairc acid, epigallo catechin gallate, ferulic acid, kaempferol, safflower yellow(Sigma-Aldrich Co., St Louis, MO, USA)를 사용하였다.

\section{$\mathrm{DPPH}$ radical 소거활성 측정}

1,1-Diphenyl-2-picrylhydrazyl(DPPH) radical 소거활성은 안정한 free radical인 $\mathrm{DPPH}$ 의 환원력을 이용하여 측정하였 다(Bios, 1958). DPPH reagent는 DPPH(Sigma-Aldrich Co.) $0.012 \mathrm{~g}$ 을 $99.9 \%$ ethanol에 충분히 용해시킨 후 동일한 양의 증류수를 첨가하여 제조하였다. 시료 $0.5 \mathrm{~mL}$ 에 $\mathrm{DPPH}$ reagent 시약 $5 \mathrm{~mL}$ 를 첨가하여 혼합 후 실온에서 15 분간 반응시킨 다 음 분광광도계(Ultraspec 2100pro, Biochrom Ltd. Cambridge, $\mathrm{UK}$ )를 사용하여 $517 \mathrm{~nm}$ 에서 흡광도를 측정하였다. $\mathrm{DPPH}$ radical 소거활성은 시료 첨가 전과 후의 차이를 아래와 같이 계산하여 나타내었다.

DPPH radical scavenging activity $(\%)=$

$$
\left(1-\frac{\text { sample absorbance }}{\text { control absorbance }}\right) \times 100
$$

\section{ABTS radical 소거활성 측정}

2,2'-Azino-bis(3-ethylbenzothianzoline-6-sulfonic acid) (ABTS) radical 소거활성은 양이온( $\left.\mathrm{ABTS}^{+}\right)$에 대한 항산화 물질의 소거능을 이용하여 측정하였다( $\operatorname{Re}$ 등, 1999). ABTS reaction mixture는 $7.4 \mathrm{mM}$ ABTS(Sigma-Aldrich Co.)와 $2.6 \mathrm{mM} \mathrm{K}_{2} \mathrm{~S}_{2} \mathrm{O}_{8}$ 의 농도로 제조하고, 실온의 암소에서 24시 간 동안 반응시켜 $\mathrm{ABTS}$ free radical을 생성시킨 후 $732 \mathrm{~nm}$ 
에서 흡광도 값이 $0.7 \pm 0.03$ 이 되게 증류수를 사용하여 희석 하였다. 시료 $50 \mu \mathrm{L}$ 에 $\mathrm{ABTS}$ reaction mixture $950 \mu \mathrm{L}$ 를 첨 가하여 혼합 후 실온에서 10 분간 반응시켜 준 다음 분광광 도계(Ultraspec 2100pro, Biochrom Ltd.)를 사용하여 732 $\mathrm{nm}$ 에서 흡광도를 측정하였다. ABTS radical 소거활성은 시료 첨가 전과 후의 차이를 아래와 같이 계산하여 나타내 었다.

ABTS radical scavenging activity $(\%)$

$$
\left(1-\frac{\text { sample absorbance }}{\text { control absorbance }}\right) \times 100
$$

\section{FRAP(ferric reducing antioxidant power) 측정}

FRAP 측정은 Benzie와 Strain(1996)의 방법에 따라 산화 및 환원 능력을 이용하여 측정하였다. FRAP reagent는 300 $\mathrm{mM}$ acetate buffer(pH 3.6) $25 \mathrm{~mL}$ 에 $40 \mathrm{mM} \mathrm{HCl}$ 에 용해한 $10 \mathrm{mM}$ 2,4,6-tris(2-pyridyl)-s-triazine(TPTZ, Sigma-Aldrich Co.) $2.5 \mathrm{~mL}$ 와 $20 \mathrm{mM}$ ferric chloride solution $\left(\mathrm{FeCl}_{3}\right.$. $\left.6 \mathrm{H}_{2} \mathrm{O}\right) 2.5 \mathrm{~mL}$ 를 혼합하여 제조하였다. 시료 $25 \mu \mathrm{L}$ 에 실험직 전 $37^{\circ} \mathrm{C}$ 에서 10 분 이상 반응시킨 FRAP reagent를 $175 \mu \mathrm{L}$ 첨가한 후 $37^{\circ} \mathrm{C}$ 로 조절된 암소에서 30 분간 반응시킨 다음 분 광광도계(Ultraspec 2100pro, Biochrom Ltd.)를 사용하여 $590 \mathrm{~nm}$ 에서 흡광도를 측정하였다. $\mathrm{FRAP}$ 측정은 $\mathrm{FeSO}_{4}$. $7 \mathrm{H}_{2} \mathrm{O}$ (Sigma-Aldrich Co.)를 정량하여 작성한 표준곡선을 이 용하여 계산하였다.

\section{Superoxide radical 소거활성 측정}

Superoxide radical 소거활성은 Nishikimi 등(1972)의 방법 에 따라 측정하였다. 시료 $500 \mu \mathrm{L}$ 에 $0.1 \mathrm{M}$ Tris- $\mathrm{HCl}$ buffer (pH 8.5) $100 \mu \mathrm{L}$ 와 $100 \mu \mathrm{M}$ phenazine methosulfate(PMS, Sigma-Aldrich Co.) $200 \mu \mathrm{L}$ 를 첨가하여 반응시킨 후 $500 \mu$ M nitro blue tetrazolium(NBT, Sigma-Aldrich Co.) $200 \mu \mathrm{L}$ 및 $500 \mu \mathrm{M} \beta$-nicotinamide adenine dinucleotide(NADH, Sigma-Aldrich Co.) $400 \mu \mathrm{L}$ 를 혼합하여 실온에서 10 분 동안 반응시킨 다음 분광광도계(Ultraspec 2100pro, Biochrom Ltd.)를 사용하여 $560 \mathrm{~nm}$ 에서 흡광도를 측정하였다. Superoxide radical 소거활성은 시료 첨가 전과 후의 차이를 아래 와 같이 계산하여 나타내었다.

Superoxide radical scavenging activity $(\%)=$

$$
\left(1-\frac{\text { sample absorbance }}{\text { control absorbance }}\right) \times 100
$$

\section{통계처리}

실험결과는 평균 \pm 표준편차로 나타내었고 $\operatorname{SPSS}(19.0, \mathrm{SPSS}$ Inc., Chicago, Il, USA)를 이용한 분산분석(ANOVA)을 실시 하였으며, 각 측정 평균값의 유의성 $(\mathrm{p}<0.05)$ 은 Duncan's multiple range test로 검정하였다.

\section{결과 및 고찰}

\section{수율 및 수분함량}

홍화 $80 \%$ 에탄올 추출물을 동결건조 및 분무건조한 분말 의 수율과 수분함량의 결과는 Table 1 과 같다. 수율은 동결건 조 분말을 제외한 분무건조 분말에서 $68.02-87.68 \%$ 로 나타 났으며, 부형제의 함량이 증가할수록 수율이 증가하는 경향 을 나타내었고 maltodextrin $20 \%$ 첨가구에서 $87.68 \%$ 로 가장 높은 수율을 확인하였다. Bhandari 등(1997)에 따르면 50\% 이상의 수율이 성공적인 분무건조로 사용된다고 보고했으며, 홍화 분무건조 분말 모두 $50 \%$ 이상의 수율을 나타냄을 확인 하였다. 수분함량은 동결건조 분말이 $1.19 \%$, 분무건조 분말 2.19-3.18\%로 나타나 동결건조 분말보다 분무건조 분말에서 유의적으로 높게 나타내었고, 분무건조 분말에서는 maltodextrin $10 \%$ 첨가구에서 $3.18 \%$ 로 가장 높은 함량을 나타내 었다. Rosenberg 등(1990)의 연구에서 미세캡슐 분말의 수분 함량은 $5 \%$ 전후의 낮은 수분함량을 나타내 저장 시 수분에 의한 분말의 고화현상이 발생하지 않는다고 보고하여 홍화의 동결건조 및 분무건조 분말 모두 $5 \%$ 이내의 함량을 나타내

Table 1. Yield and moisture content of spray-dried powders from safflower extracts

\begin{tabular}{ccc}
\hline Sample $^{1)}$ & $\begin{array}{c}\text { Yield } \\
(\text { dry basis, \%) }\end{array}$ & $\begin{array}{c}\text { Moisture content } \\
(\%)\end{array}$ \\
\hline FD & - & $1.19 \pm 0.21^{\mathrm{d} 2)}$ \\
CD10 & 68.02 & $2.21 \pm 0.12^{\mathrm{c}}$ \\
CD20 & 81.98 & $2.19 \pm 0.31^{\mathrm{c}}$ \\
MD10 & 73.38 & $3.18 \pm 0.20^{\mathrm{a}}$ \\
MD20 & 87.68 & $2.26 \pm 0.11^{\mathrm{c}}$ \\
CDMD10 & 77.43 & $2.90 \pm 0.21^{\mathrm{ab}}$ \\
CDMD20 & 82.19 & $2.72 \pm 0.30^{\mathrm{b}}$ \\
\hline
\end{tabular}

${ }^{1)} \mathrm{FD}$, freeze-dried powder; CD10, spray-dried powder with $10 \%$ cyclodextrin; CD20, spray-dried powder with $20 \%$ cyclodextrin; MD10, spray-dried powder with $10 \%$ maltodextrin; MD20, spray-dried powder with $20 \%$ maltodextirn; CDMD10, spray-dreid powder with $5 \%$ cyclodextrin and $5 \%$ maltodextrin; CDMD20, spray-dried powder with $10 \%$ cyclodextrin and $10 \%$ maltodextrin.

${ }^{2)}$ All values are mean \pm SD. Different letters $\left({ }^{\mathrm{a}-\mathrm{d}}\right)$ within a row are significantly different by Duncan's multiple range test at $\mathrm{p}<0.05$. 
었음을 확인하였다.

\section{색도, 입자크기 및 입자표면구조}

홍화 분무건조 분말의 색도, 입자크기 및 입자표면구조는 Table 2 및 Fig. 1과 같다. 색도는 동결건조 분말이 각각 L값 (35.53), a값(3.33), b값(2.01)으로 나타났고, 분무건조 분말에 서 $\mathrm{L}$ 값은 41.86-44.22을 나타내었으며, $\mathrm{a}$ 값 및 $\mathrm{b}$ 값은 6.687.63 및 16.31-19.48로 나타나 전체적으로 분무건조 분말에 서 색도가 모두 증가하는 경향을 나타내었다. Marshall 등 (2005)은 천연색소의 색상은 입자크기가 매우 중요한 역할을 하며, 미세캡슐화과정에서 입자크기 감소로 인한 비표면적이 증가하여 색도의 값이 모두 증가한 경향을 나타낸 것으로 사 료된다고 보고하였다. 홍화 분무건조 분말의 입자크기는 동 결건조 분말에서 $1,023.33 \mu \mathrm{m}$ 로 나타났고, 분무건조 분말에 서 27.88-91.20 $\mu \mathrm{m}$ 로 나타나 분무건조 분말이 유의적으로 작 았으며, 부형제의 첨가량이 증가할수록 입자크기가 커지는 것을 확인할 수 있었다. Kang 등(2002)은 일반적으로 미세캡 슐 분말의 입자크기는 1-200 $\mu \mathrm{m}$ 의 범위로 분포한다고 보고 하여 홍화의 분무건조 분말 입자크기 범위와 비슷한 경향을 확인하였고, Seo 등(2002)은 분말의 크기가 작으면 큰 입자 에 비해 많은 반응표면적을 가지게 되므로 다른 물질과 활발 한 접촉이 가능하여 반응정도, 용해정도 및 이화학적 기능성 등을 기대할 수 있다고 보고하였다. 분말의 입자 형태는 캡슐 화되기 전 원래의 물질구조에 따라 달라지지만, 일반적으로 구형이 이상적이라고 할 수 있다(Hwang 등, 2002). 입자표면 구조는 분무건조 분말에서 전반적으로 구형의 형태를 나타내 었으며, 부형제의 함량이 증가할수록 입자크기가 커지는 것을 확인하였다. 이는 미립구의 크기가 제조시 사용한 고분자의
분자량, 농도, 점도 및 유화제의 양, 제조온도 및 물리적 교반 기와 교반속도 등에 의해 영향을 받는다고 사료된다(Park 등, 2008). 또한 Lee 등(1997)은 gum arabic과 maltodextrin을 비 율별로 제조하여 분무건조한 다당류의 분말은 원형의 캡슐이 고르게 관찰되었고, 농도가 높을수록 비교적 큰 입자가 생성 되었다고 보고하여 본 연구결과와 유사한 경향을 나타내었다.

\section{수분흡수지수 및 수분용해지수}

홍화 분무건조 분말의 수분흡수지수 및 수분용해지수의 측정결과는 Table 3 과 같다. 수분흡수능(water absorption capacity)은 분말이 수분을 흡수하고 팽윤하여 식품에서 점도 를 향상시킬 수 있는 능력을 의미하고, 수분용해도는 분말이 수분에 용해되는 정도를 의미한다(Kim 등, 2012). 먼저 수분 흡수지수는 동결건조 분말에서 0.79 로 가장 높았으며, 분무 건조 분말은 0.55-0.61로 분석되었는데, 특히 cyclodextrin, maltodextrin 및 이들 동량혼합물을 각각 $10 \%$ 첨가한 분무건 조 분말에서 모두 0.55 로 가장 낮게 나타났다. Lee와 Hong (2015)의 연구에 따르면 비결정성 물질은 분자가 규칙적으로 배열되지 않은 유리질 상태의 고체를 의미하는데, 비결정성 부분이 적고 결정성 부분이 클수록 입자의 치밀도가 높아져 수분흡수지수가 낮아진다고 보고하였다. 따라서 본 연구의 분무건조 분말에서도 균일한 입자분포를 보여 낮은 수분흡수 지수가 나타난 것으로 사료된다. 또한 cyclodextrin 및 maltodextrin 첨가량이 낮을수록 흡수지수가 낮아지는 결과는 Biliaderis 등(1999)의 연구에서 dextrin 값이 낮을수록 부형 제의 물리화학적 특성의 차이로 흡습성이 함께 낮아지는 경 향을 보인다고 보고되었다. 수분용해지수는 동결건조 분말에 서 78.67\%였고, 분무건조 분말에서 90.67-96.67\%로 모두

Table 2. Color value and particle diameter of spray-dried powders from safflower extracts

\begin{tabular}{|c|c|c|c|c|}
\hline \multirow{2}{*}{ Sample ${ }^{1)}$} & \multicolumn{3}{|c|}{ Color value } & \multirow{2}{*}{$\begin{array}{l}\text { Particle size } \\
\qquad(\mu \mathrm{m})\end{array}$} \\
\hline & $\mathrm{L}$ & $\mathrm{a}$ & $\mathrm{b}$ & \\
\hline FD & $35.53 \pm 0.56^{\mathrm{e} 2)}$ & $3.33 \pm 0.37^{\mathrm{e}}$ & $2.01 \pm 0.29^{\mathrm{d}}$ & $1,023.33 \pm 12.50^{\mathrm{a}}$ \\
\hline $\mathrm{CD} 10$ & $41.86 \pm 0.18^{\mathrm{d}}$ & $7.42 \pm 0.20^{\mathrm{ab}}$ & $16.31 \pm 0.69^{\mathrm{c}}$ & $27.88 \pm 0.05^{\mathrm{f}}$ \\
\hline $\mathrm{CD} 20$ & $43.19 \pm 0.28^{\mathrm{c}}$ & $6.68 \pm 0.24^{\mathrm{d}}$ & $18.03 \pm 0.86^{\mathrm{b}}$ & $41.52 \pm 1.47^{\mathrm{e}}$ \\
\hline MD10 & $43.35 \pm 0.42^{\mathrm{c}}$ & $7.63 \pm 0.18^{\mathrm{a}}$ & $18.62 \pm 0.51^{\mathrm{ab}}$ & $43.12 \pm 1.51^{\mathrm{de}}$ \\
\hline MD20 & $44.04 \pm 0.23^{\mathrm{ab}}$ & $6.99 \pm 0.20^{\mathrm{bcd}}$ & $19.11 \pm 0.61^{\mathrm{ab}}$ & $52.02 \pm 1.40^{\mathrm{d}}$ \\
\hline CDMD10 & $43.41 \pm 0.54^{\mathrm{bc}}$ & $7.28 \pm 0.18^{\mathrm{abc}}$ & $18.17 \pm 0.94^{\mathrm{b}}$ & $66.59 \pm 5.74^{\mathrm{c}}$ \\
\hline CDMD20 & $44.22 \pm 0.24^{\mathrm{a}}$ & $6.96 \pm 0.19^{\mathrm{cd}}$ & $19.48 \pm 0.57^{\mathrm{a}}$ & $91.20 \pm 1.14^{\mathrm{b}}$ \\
\hline
\end{tabular}

${ }^{1)} \mathrm{FD}$, freeze-dried powder; CD10, spray-dried powder with $10 \%$ cyclodextrin; CD20, spray-dried powder with $20 \%$ cyclodextrin; MD10, spray-dried powder with $10 \%$ maltodextrin; MD20, spray-dried powder with $20 \%$ maltodextirn; CDMD10, spray-dreid powder with $5 \%$ cyclodextrin and $5 \%$ maltodextrin; CDMD20, spray-dried powder with $10 \%$ cyclodextrin and $10 \%$ maltodextrin.

${ }^{2)}$ All values are mean \pm SD. Different letters $\left({ }^{\mathrm{a}-\mathrm{f}}\right)$ within a row are significantly different by Duncan's multiple range test at $\mathrm{p}<0.05$. 


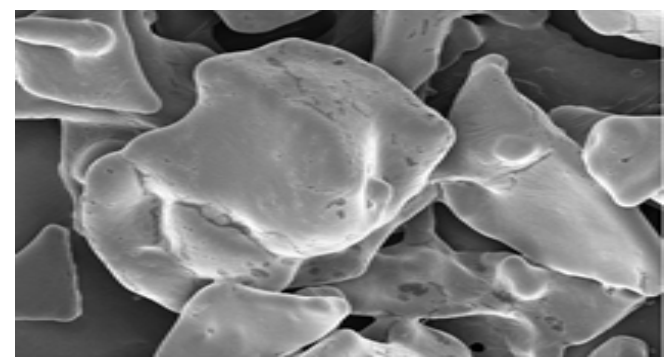

$\mathrm{FD}(3.0 \mathrm{kv} \times 100)$

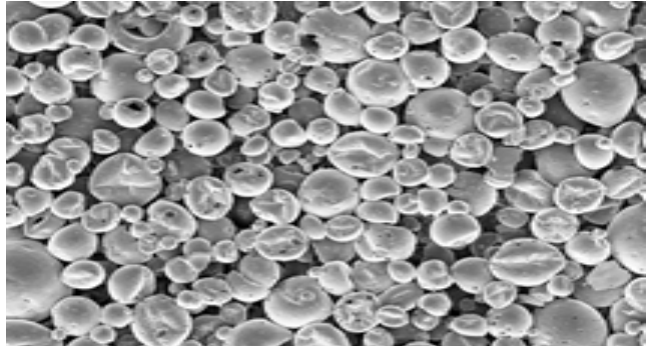

CD10

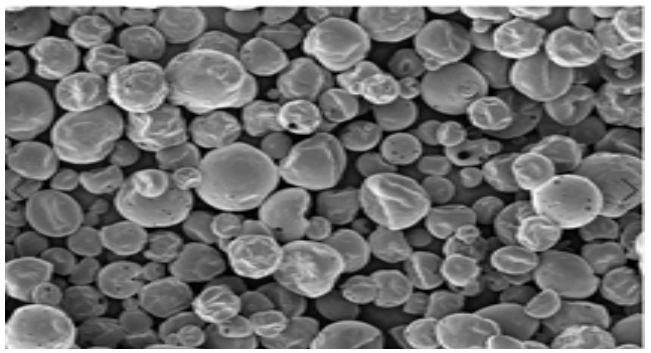

MD10

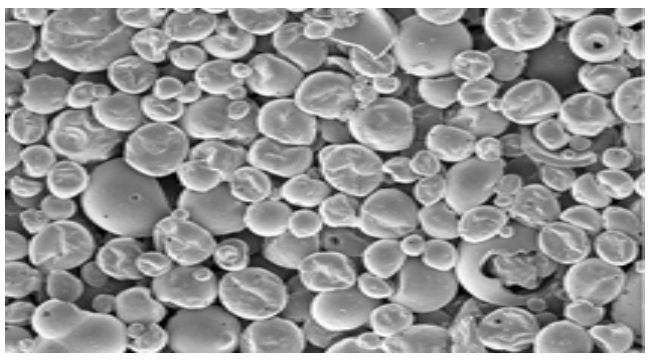

CDMD10

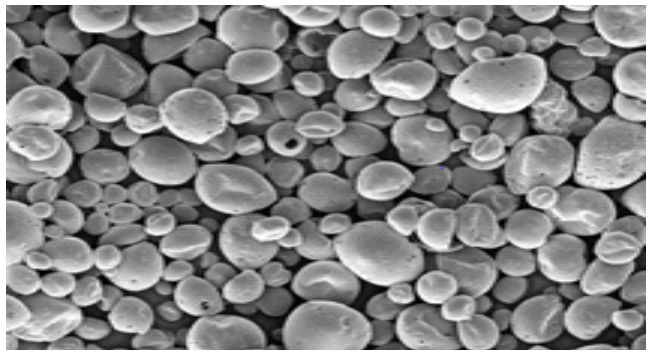

CD20

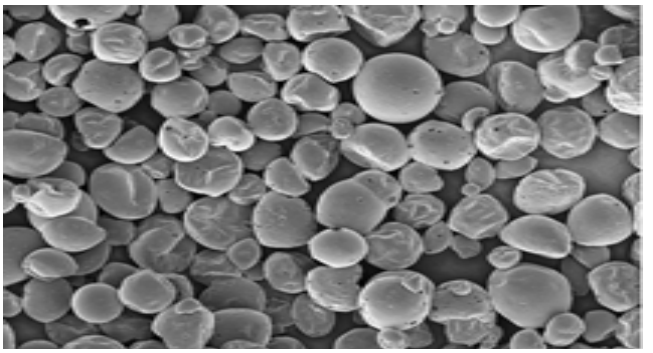

MD20

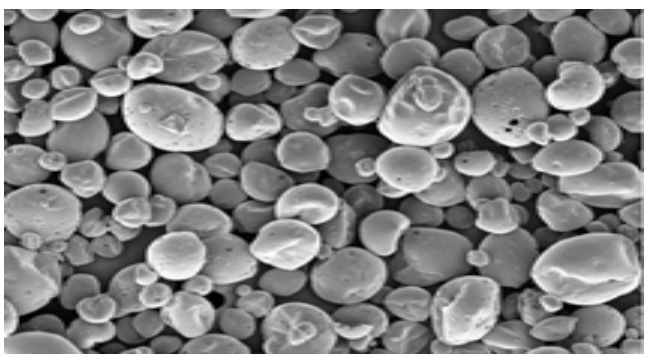

CDMD20

Fig. 1. Scanning electron microscope $(3.0 \mathrm{kV} \times 500)$ of spray-dried powders from safflower extracts.

FD, freeze-dried powder; CD10, spray-dried powder with $10 \%$ cyclodextrin; CD20, spray-dried powder with $20 \%$ cyclodextrin; MD10, spray-dried powder with $10 \%$ maltodextrin; MD20, spray-dried powder with $20 \%$ maltodextirn; CDMD10, spray-dreid powder with $5 \%$ cyclodextrin and $5 \%$ maltodextrin; CDMD20, spray-dried powder with $10 \%$ cyclodextrin and $10 \%$ maltodextrin.

$90 \%$ 이상의 높은 수분용해지수가 나타난 것을 확인하였다. Choi 등(2006)에 따르면 입자크기가 작을수록 수분용해지수 가 증가한다는 보고하였는데 동결건조 분말보다 분무건조 분 말에서 작은 입자크기에 따른 결과로 판단된다. Maltodextrin $20 \%$ 첨가구(96.67\%)에서 cyclodextrin 및 동량혼합물로 제
조된 분무건조 분말(90.67-96.00\%)보다 높은 수분용해지수 를 나타내었는데, 이는 maltodextrin이 당에 의한 수산기와 이중층 표면에 있는 인산염기 간 상호작용이 일어남에 따른 용해성 증가로 사료된다(Lee와 Hong, 2015). Chae와 Hong (2016)은 식품 가공 산업측면에서 수분흡수지수 및 수분용해 
Table 3. Water absorption index and water solubility index of spray-dried powders from safflower extracts

\begin{tabular}{ccc}
\hline Sample $^{1)}$ & $\begin{array}{c}\text { Water absorption index } \\
\text { (WAI) }\end{array}$ & $\begin{array}{c}\text { Water solubility index } \\
\text { (WSI \%) }\end{array}$ \\
\hline FD & $0.79 \pm 0.06^{\mathrm{a} 2)}$ & $78.67 \pm 1.15^{\mathrm{e}}$ \\
$\mathrm{CD} 10$ & $0.55 \pm 0.05^{\mathrm{b}}$ & $90.67 \pm 1.15^{\mathrm{d}}$ \\
$\mathrm{CD} 20$ & $0.59 \pm 0.03^{\mathrm{b}}$ & $94.00 \pm 0.00^{\mathrm{b}}$ \\
MD10 & $0.55 \pm 0.08^{\mathrm{b}}$ & $92.00 \pm 0.00^{\mathrm{cd}}$ \\
MD20 & $0.57 \pm 0.01^{\mathrm{b}}$ & $96.67 \pm 1.15^{\mathrm{a}}$ \\
CDMD10 & $0.55 \pm 0.05^{\mathrm{b}}$ & $92.67 \pm 1.15^{\mathrm{bc}}$ \\
CDMD20 & $0.61 \pm 0.06^{\mathrm{b}}$ & $96.00 \pm 0.00^{\mathrm{a}}$ \\
\hline
\end{tabular}

${ }^{1)} \mathrm{FD}$, freeze-dried powder; CD10, spray-dried powder with $10 \%$ cyclodextrin; CD20, spray-dried powder with $20 \%$ cyclodextrin MD10, spray-dried powder with $10 \%$ maltodextrin; MD20, spray-dried powder with $20 \%$ maltodextirn; CDMD10, spray-dreid powder with $5 \%$ cyclodextrin and 5\% maltodextrin; CDMD20, spray-dried powder with $10 \%$ cyclodextrin and $10 \%$ maltodextrin

${ }^{2)}$ All values are mean \pm SD. Different letters $\left({ }^{\mathrm{a}-\mathrm{e}}\right)$ within a row are significantly different by Duncan's multiple range test at $\mathrm{p}<0.05$.

지수는 분말의 안정성에 있어서 매우 중요한 요인으로 저장 안정성 측면에서 낮은 수분흡수지수 값과 높은 수분용해지수 의 값을 요구한다고 보고하여 홍화 분무건조 분말에서 동결 건조 분말보다 낮은 수분흡수지수 값과 높은 수분용해지수의 값을 나타내어 저장안정성이 우수할 것으로 판단된다.

\section{TGA 분석 특성}

홍화 분무건조 분말의 $\mathrm{TGA}$ 분석결과는 Table 4 와 같다. $\mathrm{TGA}$ 분석은 온도 상승에 따른 무게의 변화 감소율을 나타내 며, 시료의 고분자가 연소하는 특정 온도 영역에서의 분해속 도 변화를 통해 고분자물질의 정량이 가능한 방법이다(Kim 등, 2016). 열분해 특성의 무게감소량은 4단계로 구분되었다. 먼저, 시료의 수분증발로 중량감소가 나타나는 1 단계는 20$180^{\circ} \mathrm{C}$ 부근에서 전체질량의 약 $10 \%$ 가 감소하였다. 2 단계는 입자 성분의 분해과정에 해당하고(do Carmo 등, 2018), 약 $84-230^{\circ} \mathrm{C}$ 범위에서 나타났으며, 동결건조 분말은 $26.19 \%$, 분 무건조 분말은 7.81-9.89\%의 무게감소를 보여주었다. 동결건 조 분말의 주 분해가 약 $84^{\circ} \mathrm{C}$ 이상의 범위인 2 단계에서 일어 났음을 확인하였다. 3 단계인 $226-340^{\circ} \mathrm{C}$ 범위에서는 분무건 조 분말의 급격한 질량감소가 나타나 분무건조 분말의 주 분 해온도는 대략 $283^{\circ} \mathrm{C}$ 로 나타났다. 따라서 급격한 질량감소가 나타나는 범위에서 대부분의 열분해가 일어남을 확인하였다. Janiszawka(2014)는 높은 질량 손실은 자당, 과당, 포도당 및 산과 같은 저분자량과 낮은 유리 전이온도를 나타내는 성분 의 분해와 관련이 있다고 보고하였다. $\mathrm{Seo}(2008)$ 에 따르면 cyclodextrin류의 분해에 의해 $280^{\circ} \mathrm{C}$ 에서 급격한 중량감소가
Table 4. Thermogravimetric results considering the TGA curves of spray-dried powders from safflower extracts

\begin{tabular}{|c|c|c|c|}
\hline Sample $^{1)}$ & Stage & TGA $\left({ }^{\circ} \mathrm{C}\right)$ & Weight loss $(\%)$ \\
\hline \multirow{4}{*}{ FD } & 1 & $20-84$ & 0.85 \\
\hline & 2 & $84-230$ & 26.19 \\
\hline & 3 & $230-410$ & 18.21 \\
\hline & 4 & $410-700$ & 25.30 \\
\hline \multicolumn{2}{|c|}{ Total weight loss $(\%)$} & & 70.55 \\
\hline \multirow{4}{*}{ CD10 } & 1 & $20-114$ & 12.90 \\
\hline & 2 & $114-229$ & 9.89 \\
\hline & 3 & $229-339$ & 29.55 \\
\hline & 4 & $339-700$ & 19.76 \\
\hline \multicolumn{2}{|c|}{ Total weight loss $(\%)$} & & 72.10 \\
\hline \multirow{4}{*}{$\mathrm{CD} 20$} & 1 & $20-180$ & 13.51 \\
\hline & 2 & $180-253$ & 8.51 \\
\hline & 3 & $253-340$ & 34.07 \\
\hline & 4 & $385-700$ & 18.07 \\
\hline \multicolumn{2}{|c|}{ Total weight loss $(\%)$} & & 74.16 \\
\hline \multirow{4}{*}{ MD10 } & 1 & $20-180$ & 14.18 \\
\hline & 2 & $180-230$ & 8.97 \\
\hline & 3 & $230-339$ & 29.60 \\
\hline & 4 & $339-700$ & 19.47 \\
\hline \multicolumn{2}{|c|}{ Total weight loss $(\%)$} & & 72.22 \\
\hline \multirow{4}{*}{ MD20 } & 1 & $20-116$ & 9.32 \\
\hline & 2 & $116-226$ & 8.71 \\
\hline & 3 & $226-333$ & 37.81 \\
\hline & 4 & $333-700$ & 18.27 \\
\hline \multicolumn{2}{|c|}{ Total weight loss (\%) } & & 74.11 \\
\hline \multirow{4}{*}{ CDMD10 } & 1 & $20-180$ & 13.86 \\
\hline & 2 & $180-230$ & 9.89 \\
\hline & 3 & $230-339$ & 29.55 \\
\hline & 4 & $339-700$ & 18.90 \\
\hline \multicolumn{2}{|c|}{ Total weight loss (\%) } & & 72.20 \\
\hline \multirow{4}{*}{ CDMD20 } & 1 & $20-180$ & 12.81 \\
\hline & 2 & $180-230$ & 7.81 \\
\hline & 3 & $230-340$ & 34.13 \\
\hline & 4 & $340-700$ & 18.12 \\
\hline
\end{tabular}

Total weight loss $(\%)$

72.87

${ }^{1)} \mathrm{FD}$, freeze-dried powder; CD10, spray-dried powder with $10 \%$ cyclodextrin; CD20, spray-dried powder with $20 \%$ cyclodextrin; MD10, spray-dried powder with $10 \%$ maltodextrin; MD20, spray-dried powder with $20 \%$ maltodextrin; CDMD10, spray-dried powder with $5 \%$ cyclodextrin and 5\% maltodextrin; CDMD20, spray-dried powder with $10 \%$ cyclodextrin and $10 \%$ maltodextrin. 
나타났다고 보고하였는데, 본 연구에서도 부형제인 cyclodextrin, maltodextrin 및 동량 혼합물이 $10 \%$ 첨가된 분무건 조분말(29.55-29.60)보다 $20 \%$ 를 혼합한 분무건조 분말에서 34.07-37.81로 더 큰 중량감소가 일어남을 확인하였다. 4단 계에 속하는 $600^{\circ} \mathrm{C}$ 이후로 질량감소는 거의 일어나지 않아 고체 상태의 분말에 함유된 물 분자의 이탈이 일어난 것을 알 수 있으며, 초기량 대비 25.84-29.45\%의 잔류물질이 남은 것을 확인하였다. 분석결과를 종합할 때, 동결건조 분말보다 분무건조 분말에서 열안정성이 우수한 것을 알 수 있었다. Chae 등(2015)은 일반적으로 식품공정에서 사용하는 고온 공정이 $300^{\circ} \mathrm{C}$ 를 넘지 않는다고 보고하여 열적 특성이 안정한 분무건조 분말이 고온이 요구되는 가공공정에 적용 가능할 것으로 사료된다.

\section{페놀화합물}

홍화 분무건조 분말의 페놀화합물 분석결과는 Table 5 와 같다. 식물계에 널리 분포되어 있는 페놀화합물은 벤젠고리 에 있는 수소 $(\mathrm{H})$ 가 수산기 $(-\mathrm{OH})$ 로 치환된 페놀로 이루어진 물질이며, 한 개 또는 두 개 이상의 수산기(hydroxyl group) 로 치환된 방향족 고리를 가지고 phenolic acid류, coumarin 류, flavonoid류, tannin류로 나뉘며, 그 구조에 따라 이화학 적 성질 및 생리적 기능이 달리 나타난다고 알려져 있다(Cho 등, 2012). 홍화 분무건조 분말의 페놀화합물을 분석한 결과, Choi 등(2011)의 연구보고와 같이 $p$-coumaric acid, epigallocatechin gallate 및 ferulic acid가 있으며, flavonoid 성분인 kaempferol 및 quinochalcone계 색소성분인 safflower yellow 가 분리되었다. 동결건조 분말의 페놀화합물 함량은 1.46 $\mathrm{g} / 100 \mathrm{~g}$ 으로 나타났으며, 분무건조 분말은 $0.20-1.07 \mathrm{~g} / 100$ $\mathrm{g}$ 으로 분석되었는데, maltodextrin $10 \%$ 첨가구 $(1.07 \mathrm{~g} / 100$ $\mathrm{g})$, cyclodextrin $10 \%$ 첨가구 $(1.06 \mathrm{~g} / 100 \mathrm{~g}$ ) 및 cyclodextrin $20 \%$ 첨가구 $(0.88 \mathrm{~g} / 100 \mathrm{~g})$ 순으로 높은 함량을 나타내었다. Shahidi와 Han(1993)은 cyclodextrin은 starch에 cyclodextrin glucanotransferase를 작용시켜 얻어진 환상구조의 물질로 강 한 포집능을 가진다는 보고와 같이 cyclodextrin을 첨가한 분 무건조분말에서 우수한 페놀화합물 함량을 나타내는 것을 확 인하였다. 또한 maltodextrin $10 \%$ 첨가구 $(1.07 \mathrm{~g} / 100 \mathrm{~g})$ 와 maltodextrin $20 \%$ 첨가구 $(0.21 \mathrm{~g} / 100 \mathrm{~g})$ 의 페놀화합물 함량 의 차이는 Mishara 등(2014)의 연구에서 maltodextrin 농도가 $5 \%$ 에서 $9 \%$ 로 증가할 때 분말의 페놀함량이 현저히 감소하 여 부형제 혼합 농도의 차이에 따른 결과라고 보고하였으며, cyclodextrin 및 maltodextrin의 동량 화합물 분무건조분말에 서는 홍화의 주요 페놀화합물인 keampferol 및 safflower yellow가 용해되지 않아 낮은 페놀화합물의 함량이 나타난 것으로 판단된다. 총 페놀화합물은 동결건조 분말 대비 분무 건조 분말에서 유의적으로 낮은 함량을 나타내었는데, 이는 total phenolic compound와 같은 유용성분은 열처리에 민감 해 건조, 가열 등의 과정 중 분해되기 쉽다는 연구결과로 사 료된다(Sormoli와 Langrish, 2016). 그러나 건조방법 중 분무 건조는 건조온도가 $130-300^{\circ} \mathrm{C}$ 범위로 비교적 높음에도 불구 하고, 원료가 열과 접촉하는 시간은 5-20초 이내로 열에 의한 성분변화가 미비하며, 다른 반응들로부터 활성물질을 보호하는 데 유리하다고 보고하여 분무건조 분말을 통해 생리활성 물질 안정성을 높일 수 있다고 판단된다(Boatright와 Hettiarachchy, 1995; Fuches 등, 2004). 분석된 페놀화합물 중 $p$-coumaric acid는 항산화, 항균, 항바이러스 및 면역조절효과가 있고, epigallocatechin gallate는 항산화 및 항암의 작용이 보고된다

Table 5. Phenolic compounds of spray-dried powders form safflower extracts

\begin{tabular}{ccccccc}
\hline Sample $^{\mathrm{l})}$ & p-Coumaric acid & $\begin{array}{c}\text { Epigallo catechin } \\
\text { gallate }\end{array}$ & Ferulic acid & Kaempferol & Safflower yellow & Total \\
\hline FD & $0.12 \pm 0.00^{\mathrm{a} 2}$ & $0.17 \pm 0.00^{\mathrm{a}}$ & $0.15 \pm 0.01^{\mathrm{a}}$ & $0.45 \pm 0.01^{\mathrm{a}}$ & $0.57 \pm 0.01^{\mathrm{a}}$ & 1.46 \\
$\mathrm{CD} 10$ & $0.03 \pm 0.01^{\mathrm{c}}$ & $0.15 \pm 0.01^{\mathrm{ab}}$ & $0.09 \pm 0.01^{\mathrm{b}}$ & $0.34 \pm 0.03^{\mathrm{b}}$ & $0.45 \pm 0.00^{\mathrm{c}}$ & 1.06 \\
CD20 & $0.03 \pm 0.01^{\mathrm{c}}$ & $0.12 \pm 0.02^{\mathrm{c}}$ & $0.08 \pm 0.02^{\mathrm{b}}$ & $0.23 \pm 0.00^{\mathrm{c}}$ & $0.42 \pm 0.00^{\mathrm{d}}$ & 0.88 \\
MD10 & $0.05 \pm 0.01^{\mathrm{b}}$ & $0.13 \pm 0.00^{\mathrm{bc}}$ & $0.08 \pm 0.01^{\mathrm{b}}$ & $0.34 \pm 0.06^{\mathrm{b}}$ & $0.47 \pm 0.00^{\mathrm{b}}$ & 1.07 \\
MD20 & $0.03 \pm 0.00^{\mathrm{c}}$ & $0.13 \pm 0.00^{\mathrm{bc}}$ & $0.05 \pm 0.02^{\mathrm{b}}$ & $\mathrm{ND}^{3)}$ & $\mathrm{ND}$ & 0.21 \\
CDMD10 & $\mathrm{ND}$ & $0.14 \pm 0.02^{\mathrm{bc}}$ & $0.06 \pm 0.00^{\mathrm{b}}$ & $\mathrm{ND}$ & $\mathrm{ND}$ & 0.20 \\
CDMD20 & $0.02 \pm 0.00^{\mathrm{d}}$ & $0.12 \pm 0.00^{\mathrm{c}}$ & $0.06 \pm 0.00^{\mathrm{b}}$ & $\mathrm{ND}$ & $\mathrm{ND}$ & 0.20 \\
\hline
\end{tabular}

${ }^{1)} \mathrm{FD}$, freeze-dried powder; CD10, spray-dried powder with $10 \%$ cyclodextrin; CD20, spray-dried powder with 20\% cyclodextrin; MD10, spray-dried powder with $10 \%$ maltodextrin; MD20, spray-dried powder with $20 \%$ maltodextirn; CDMD10, spray-dreid powder with 5\% cyclodextrin and $5 \%$ maltodextrin; CDMD20, spray-dried powder with $10 \%$ cyclodextrin and $10 \%$ maltodextrin

${ }^{2)}$ All values are mean \pm SD. Different letters $\left({ }^{\mathrm{a}-\mathrm{d}}\right)$ within a row are significantly different by Duncan's multiple range test at $\mathrm{p}<0.05$.

${ }^{3)}$ Not detectable. 
(Ahmad 등, 1997; Jang 등,2019). Ferulic acid는 활성산소 중 화작용, 지질산화억제 작용이 우수하다고 알려져 있다(Song 등, 2013). Kaempferol 및 safflower yellow 또한 체내에서 항 산화, 항염증 등의 생리활성을 조절한다고 알려져 동결건조 분말을 제외하고 분무건조 중 maltodextrin $10 \%$ 첨가구에서 각 유용성분이 가장 많이 함유되어 우수한 생리활성을 나타 낼 것으로 사료된다(Jung 등, 2019; Kim 등, 2019).

\section{$\mathrm{DPPH}$ 및 $\mathrm{ABTS}$ radical 소거활성}

홍화 분무건조 분말의 DPPH 및 $\mathrm{ABTS}$ radical 소거활성은 Fig. 2와 같다. DPPH radical 소거활성은 $100-1,000 \mu \mathrm{g} / \mathrm{mL}$ 농도에서 측정하였으며, 시료 모두 농도가 증가함에 따라 활 성이 증가하였다. 부형제를 첨가하지 않은 동결건조 분말은

(A)

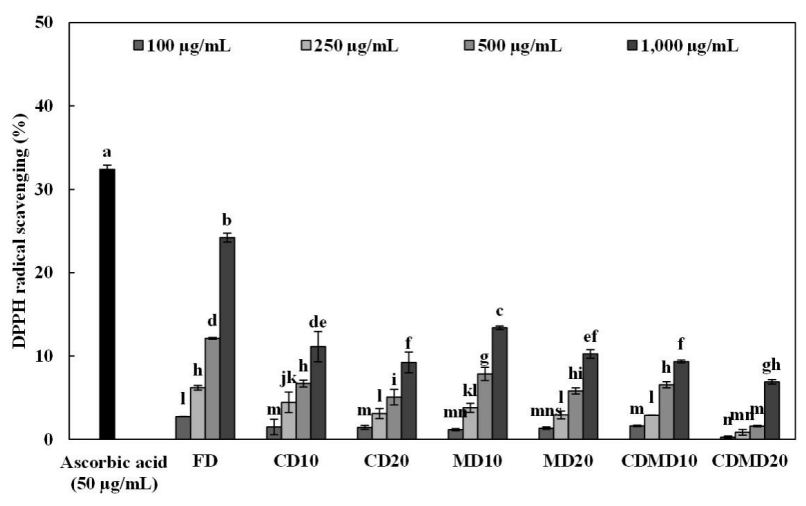

(B)

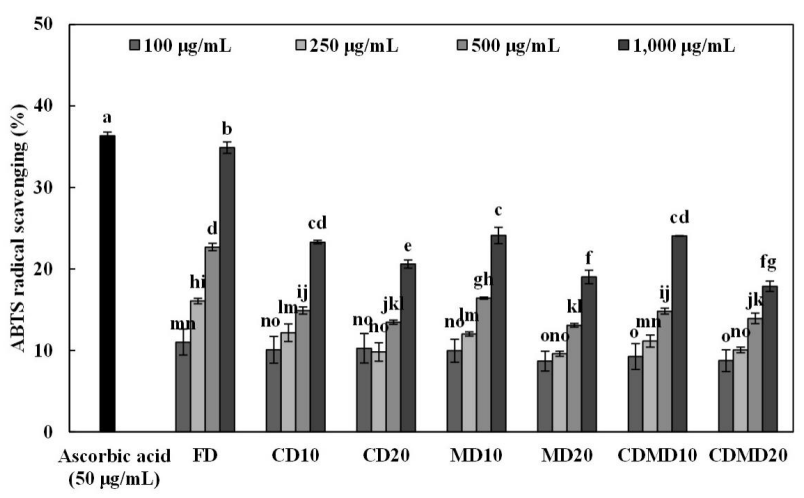

Fig. 2. DPPH (A) and ABTS (B) radical scavenging activity of spray-dried powders from safflower extracts.

FD, freeze-dried powder; CD10, spray-dried powder with $10 \%$ cyclodextrin; CD20, spray-dried powder with $20 \%$ cyclodextrin; MD10, spray-dried powder with $10 \%$ maltodextrin; MD20, spray-dried powder with $20 \%$ maltodextrin; CDMD10, spray-dried powder with $5 \%$ cyclodextrin and 5\% maltodextrin; CDMD20, spray-dried powder with $10 \%$ cyclodextrin and $10 \%$ maltodextrin.

All values are mean \pm SD. Different letters $\left({ }^{\mathrm{a}-0}\right)$ above the bars are significantly different by Duncan's multiple range test at $\mathrm{p}<0.05$.
$1,000 \mu \mathrm{g} / \mathrm{mL}$ 농도에서 $24.21 \%$ 로 나타났고, 분무건조 분말은 $0.28-13.40 \%$ 로 나타나 분무건조 분말 중 maltodextrin $10 \%$ 첨가구에서 $13.40 \%$ 로 가장 높은 항산화 활성을 나타내었다. Chang과 $\operatorname{Kim}(2011)$ 은 항산화 활성이 가열처리를 했을 경우 비타민 C와 같은 열에 약한 물질이 파괴되어 일반적으로 그 효능이 감소된다고 보고하였고, Lee 등(2014)의 연구에서도 열풍건조 오미자보다 진공동결건조 오미자의 항산화 활성이 상대적으로 높게 나타났음을 보고하여 홍화 분무건조 분말 또 한 유사한 경향이 나타났음을 확인하였다. ABTS radical 소거 활성은 화학반응을 통한 양이온 radical이 유발된 용액에 항산 화제를 넣어 측정하는 방법으로 lipophilic 또는 hydrophilic 항산화 물질의 측정에 적용 가능한 방법으로 DPPH radical 소거활성과 차이가 있다(Miller와 Rice-Evans, 1997; Yoo와 Yoo, 2005). 측정결과, $1,000 \mu \mathrm{g} / \mathrm{mL}$ 농도에서 동결건조 분말 은 $34.88 \%$ 를 나타내 가장 우수한 활성을 나타내었으며, 분무 건조 분말에서는 $17.85-24.10 \%$ 를 나타내었다. 이는 Gomes 등(2013)의 연구에서 파파야 동결건조 분말이 분무건조 분말 보다 더 높은 ABTS radical 소거능을 나타내어 본 연구와 유 사한 경향을 나타내었다. 또한 DPPH radical 소거활성과 같이 분무건조 분말 중에서는 maltodextrin $10 \%$ 첨가구 $24.10 \%$, $1,000 \mu \mathrm{g} / \mathrm{mL}$ )에서 가장 높은 활성을 나타내었으며, 앞서 실 험한 DPPH radical 소거능보다 약간 높은 항산화 활성을 나 타내었는데, 이는 ABTS radical 소거활성이 친수성 시료와 소수성 시료의 radical 소거활성을 모두 측정할 수 있으므로 다른 항산화 실험결과보다 높은 항산화능을 나타낸 것으로 판단된다(Choi와 Shin, 2015).

\section{FRAP 및 superoxide radical 소거활성}

홍화 분무건조 분말의 FRAP 활성 및 superoxide radical 소 거활성은 Fig. 3과 같다. FRAP 측정결과, $100-1,000 \mu \mathrm{g} / \mathrm{mL}$ 농도에서 동결건조 분말은 39.73-324.00 $\mu \mathrm{M}$ 로 나타났고, 분 무건조 분말은 $16.70-191.57 \mu \mathrm{M}$ 을 나타내 농도 의존적으로 항산화 활성이 증가하였다. $\mathrm{Kim}$ 등(2018)은 여러 연구결과 에서 열풍, 진공 및 동결건조의 방법으로 식품건조물을 제조 하였을 때 항산화 활성이 동결, 진공 및 열풍건조 순으로 높 은 보고하여 본 연구에서도 홍화 동결건조, 분무건조 분말 순 으로 항산화 활성이 높게 나타냄을 확인하였다. 또한 분무건 조 분말 $1,000 \mu \mathrm{g} / \mathrm{mL}$ 농도에서 maltodextirn $10 \%$ 첨가구 및 cyclodextrin와 maltodextrin 혼합 $10 \%$ 첨가구에서 각각 $191.57 \mu \mathrm{M}$ 및 $191.33 \mu \mathrm{M}$ 로 가장 높은 활성을 나타내었다. Choi 등(2015)은 FRAP 활성이 전자공여를 통한 라디칼 소 거활성과 상관성이 높은 것으로 보고하여 본 연구의 $\mathrm{DPPH}$ radical 소거활성과 FRAP 실험에서 maltodextrin $10 \%$ 첨가 구가 가장 높은 항산화 활성을 나타내 연구결과와 유사한 경 
(A)

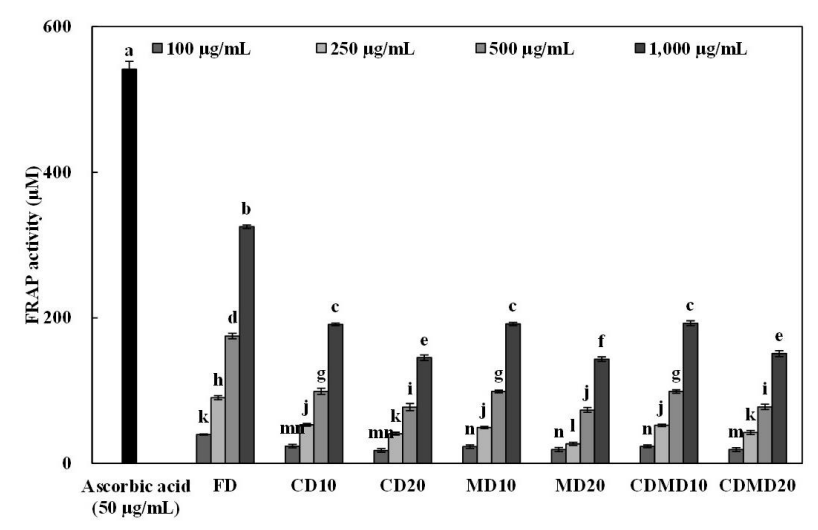

(B)

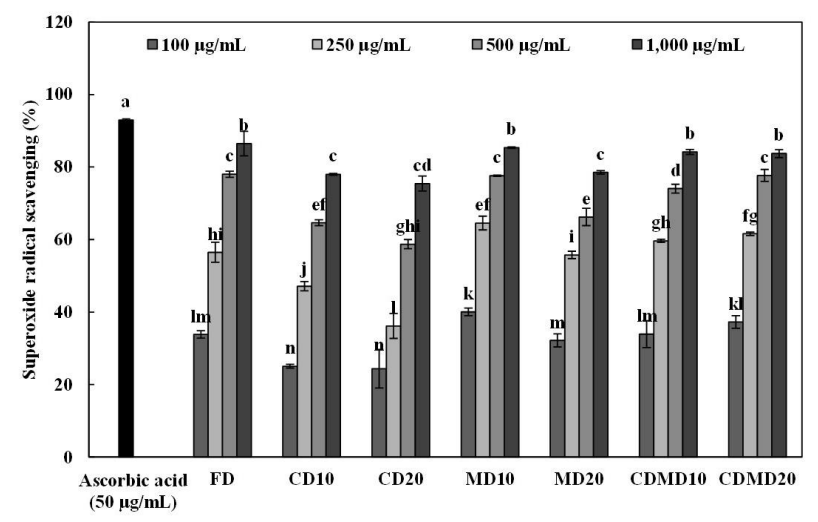

Fig. 3. FRAP (A) and Superoxide radical scavenging activity (B) of spray-dried powders from safflower extracts.

FD, freeze-dried powder; CD10, spray-dried powder with $10 \%$ cyclodextrin; CD20, spray-dried powder with $20 \%$ cyclodextrin; MD10, spray-dried powder with $10 \%$ maltodextrin; MD20, spray-dried powder with $20 \%$ maltodextrin; CDMD10, spray-dried powder with $5 \%$ cyclodextrin and 5\% maltodextrin; CDMD20, spray-dried powder with $10 \%$ cyclodextrin and $10 \%$ maltodextrin.

All values are mean \pm SD. Different letters $\left({ }^{a-n}\right)$ above the bars are significantly different by Duncan's multiple range test at $\mathrm{p}<0.05$.

향을 나타내었다. Superoxide radical 소거활성을 분석한 결 과, $1,000 \mu \mathrm{g} / \mathrm{mL}$ 농도에서 $75.47-86.50 \%$ 로 나타났으며, 동 결건조 분말 $(86.50 \%)$ 대비 분무건조 분말의 maltodextrin $10 \%$ 첨가구(85.37\%)와 유의적인 차이가 나타나지 않음을 확인하였다. Superoxide radical 소거실험은 세포 내 SODlike 효과로써 인체에 oxidative stress에 의한 DNA 손상, 염 증반응, 세포파괴로부터 보호할 수 있는 항산화 효과를 나타 낸다고 보고하였고, 본 실험에서 홍화 동결건조 및 분무건조 분말 $1,000 \mu \mathrm{g} / \mathrm{mL}$ 농도에서 $70 \%$ 이상의 superoxide radical 소거활성을 나타내어 각 시료에 함유되어있는 페놀화합물의 수소들이 $\cdot \mathrm{O}_{2}{ }^{-}$를 소거시키는 작용을 한 것으로 여겨진다 (Chung 등, 2010; Yoon 등, 2006). 또한 Yu 등(2011)은 식물
성 원료들이 지닌 페놀성 화합물은 산화 환원력에 기인한다 고 보고하였고, Ho 등(2012)은 많은 연구자들이 phenolics의 함량이 항산화와 같은 생리적 효과와 밀접한 연관성을 지닌 다고 보고하여 페놀화합물 함량이 우수한 maltodextrin $10 \%$ 첨가구에서 높은 FRAP 활성 및 superoxide radical 소거활성 이 나타난 것으로 사료된다.

\section{요 약}

본 연구에서는 홍화의 산업적 이용 증대 및 기능성 식품 가공용 소재로의 활용가능성을 확인하고자 홍화 $80 \%$ 에탄올 추출물을 분무건조한 다음 품질 특성 및 항산화 활성을 조사 하였다. 수율은 분무건조 분말에서 $68.02-87.68 \%$ 로 나타났 고, 수분함량은 maltodextrin $10 \%$ 첨가구에서 $3.18 \%$ 로 가장 높은 함량을 나타내었다. 색도는 $\mathrm{L}, \mathrm{a}, \mathrm{b}$ 값 모두 동결건조 분 말보다 분무건조 분말에서 높게 나타났다. 분무건조 분말의 입자크기는 부형제 $20 \%$ 첨가구가 $10 \%$ 첨가구보다 증가하는 경향을 나타내었으며, 입자표면구조는 전반적으로 구형의 형 태를 나타내었다. 분무건조 분말의 수분흡수지수는 0.55 $0.61 \%$ 로 나타났고, 수분용해지수는 $90 \%$ 이상으로 높은 값 을 나타내었다, TGA 분석은 분무건조 분말의 주 분해 온도 는 약 $283^{\circ} \mathrm{C}$ 로 나타나 고온의 가공공정에 적용 가능할 것으 로 사료된다. 페놀화합물은 분무건조 분말에서 0.20-1.07 $\mathrm{g} / 100 \mathrm{~g}$ 을 나타내었고, 특히 maltodextrin $10 \%$ 첨가구에서 $1.07 \mathrm{~g} / 100 \mathrm{~g}$ 으로 높은 함량을 나타내었다. DPPH radical 소 거활성 및 $\mathrm{ABTS}$ radical 소거활성은 maltodextrin $10 \%$ 첨가 구 $1,000 \mu \mathrm{g} / \mathrm{mL}$ 에서 각각 $13.40 \%$ 및 $24.10 \%$ 로 가장 높은 소거활성을 나타내었다. FRAP 활성은 분무건조 분말이 16.70-191.57 $\mu \mathrm{M}$ 의 활성을 나타내었고, superoxide radical 소거활성은 maltodextrin $10 \%$ 첨가구에서 $85.37 \%$ 로 동결건 조 분말(86.50\%)과 유의적인 차이가 나타나지 않았다.

\section{Conflict of interests}

The authors declare no potential conflict of interest.

\section{ORCID}

Mi Jeong Lim https://orcid.org/0000-0002-5254-2624

Joo-Heong Hong https://orcid.org/0000-0003-4360-3111

\section{References}

Ahmad N, Feyes DK, Nieminen AL, Agarwal R, Mukhtar $\mathrm{H}$. Green tea constituent epigallocatechin-3-gallate and 
induction of apoptosis and cell cycle arrest in human carcinoma cells. J Natl Cancer Inst, 89, 1881-1886 (1997)

Benzie IFF, Strain JJ. The ferric reducing ability of plasma (FRAP) as a measure of "antioxidant power": The FRAP assay. Anal Biochem, 239, $70-76$ (1996)

Bhandari BR, Datta M, Howes T. Problems associated with spray drying of sugar-rich food. Drying Technol, 15, 671-684 (1997)

Biliaderis CG, Swan RS, Arvanitoyannis I. Physicochemical properties of commercial starch hydrolyzates in the frozen state. Food Chem, 64, 537-546 (1999)

Blois MS. Antioxidant determinations by the use of a stable free radical. Nature, 181, 1199-1200 (1958)

Boatright WL, Hettiarachchy NS. Spray-dried soy protein isolate solubility, gelling characteristics, and extractable protein as affected by antioxidants. J Food Sci, 60, 806-809 (1995)

Chae HY, Hong JH. Quality characteristics of spray-dried powder from purple sweet potato extract. J Chitin Chitosan, 21, 271-277 (2016)

Chae HY, Lee DH, Hong JH. Quality properties and manufacturing of alginic acid bead conatining amylase by drying time. J Chitin Chitosan, 20, 182-188 (2015)

Chang Y, Kim J. Effects of pretreatment and drying methods on the quality and physiological activities of garlic powders. J Korean Soc Food Sci Nutr, 40, 1680-1687 (2011)

Chipiti T, Ibrahim MA, Koorbanally NA, Islam S. In vitro antioxidant activities of leaf and root extracts of Albizia antunesiana Harms. Acta Pol Pharm, 70, 1035-1043 (2013)

Cho JW, An TH, Lee SY, Park KW. Determination of total content of phenolic compounds in Chinese matrimony vine's accessions. Korena J Crop Sci, 57, 409-417 (2012)

Choi BK, Kum JS, Lee HY, Park JD. Physicochemical properties of black rice flours (BRFs) affected by milling conditions. Korean J Food Sci Technol, 38, 751-755 (2006)

Choi HG, Jiang YF, Park SH, Son AR, Na MK, Lee SH. Constituents of flowers of Carthamus tinctorius L. and their antioxidant activity. Kor J Pharmacogn, 42, 110116 (2011)
Choi MH, Kang JR, Sim HJ, Kang MJ, Seo WT, Bea WY, Shin JH. Physicochemical characteristics and antioxidant activity of Sumaeyaksuk depending on harvest times and processing methods. Korean J Food Preserv, 22, 399407 (2015)

Choi MH, Shin HJ. Anti-oxidative and anti-melnogenesis effects of buleberry extract. Asian J Beauty Cosmetol, 13, 261-266 (2015)

Chung HJ, Park HN, Chu YR, Jeon IS, Kang YS. Quality characteristics and antioxidant activity of syrup added with maca (Lepidium meyenii) extract. Korean J Food Preserv, 17, 236-242 (2010)

Del Valle EMM. Cyclodextrins and their uses: A review. Process Biochem, 39, 1033-1046 (2004)

do Carmo EL, Teodoro RAR, Felix PHC, de Barros Fernandes de Oliveira ER, Veiga TRLA, Borges SV, Batrel DA. Stability of spray-dried beetroot extract using oligosaccharides and whey proteins. Food Chem, 249, $51-59$ (2018)

Dzondo-Gadet M, Nzikou JM, Etoumongo A, Linder M, Desobry S. Encapsulation and storage of safou pulp oil in 6DE maltodextrins. Process Biochem, 40, 265-271 (2005)

Fuchs M, Fitzpatrick JJ, Iqbal T, Delaney C, Twomey T, Keogh MK. Effect of powder properties and storage conditions on the flowability of milk powders with different fat contents. J Food Eng, 64, 435-444 (2004)

Gomes MA, Natto AT, Campostrini E, Smith RB, Zullo MAT, Ferraz TM, Siqueira LN, Leal NR, Vazquez MN. Brassinosteroid analogue affects the senescence in two papaya genotypes submitted to drought stress. Theor Exp Plant Physiol, 25, 186-195 (2013)

Ho ST, Tung YT, Chen YL, Zhao YY, Chung MJ, Wu JH. Antioxidant activities and phytochemical study of leaf extracts from 18 indigenous tree species in Taiwan. J Evidence- Based Complementary Altern Med, 215959 (2012)

Hwang SH, Hong JH, Jeong YJ, Youn KS. Effects of the proportions of wall materials on the characteristics of spray dried vinegar. Koren J Food Preserv, 9, 189-193 (2002)

Jang MG, Ko HC, Kim SJ. Anti-proliferative properties of $p$-coumaric acid in SUN-16 gastric cancer cells. J Life Sci, 29, 809-816 (2019) 
Janiszewska E. Microencapsulated beetroot juice as a potential source of betalain. Powder Technology, 264, 190-196 (2014)

Jung YJ, Assefa AD, Lee JE, Lee HS, Rhee JH, Sung JS. Analysis of antioxidant activity and serotonin derivatives in safflower (Carthamus tinctorius L.) germplasm collected from five countries. Korean J Plant Res, 32, 423-432 (2019)

Kang GH. Antioxidative activity of phenolic compounds isolated from safflower (Carthamus tinctorius L.) seeds. MS Thesis, Catholic University of Daegu, Korea, p 1 (2001)

Kang YC, Choi KK, Kim KH, Kim HK. Microencapsulation of Aster scaber and Aster glehni by spray drying. Korean J Food Preserv, 9, 212-220 (2002)

Kim AH, Lee KY, Ha MH, Heo HJ, Choi SG. Effect of freeze, hot-air, and vacuum drying on antioxidant properites and quality characteristics of Samnamul (Aruncus dioicus var. kamtschaticus). Korean J Food Preserv, 25, 811-818 (2018)

Kim EO, Lee KT, Choi SW. Chemical comparison of germinated- and ungerminated-safflower (Carthamus tinctorius) seeds. J Korean Soc Food Sci Nutr, 37, 1162-1167 (2008)

Kim HY, Seo HI, Ko JY, Kim JI, Lee JS, Song SB, Jung TW, Kim KY, Kwak DY, Oh IS, Jeong HS, Woo KS. Physicochemical characteristics of the sorghum (Sorghum bicolor L. Moench) powder following low temperaturemicroparticulation. Korean J Food Nutr, 24, 656-663 (2012)

Kim JB, Cho MH, Hahn TR, Paik YS. Efficient purification and chemical structure identification of carthamin from Carthamus tinctorius. Agricultural Chem Biotechnol, 39, 501-505 (1996)

Kim JH, Lee SH, Cho EJ, Kim HY. Neuroprotective effects of kaempferol, quercetin, and its glycosides by regulation of apoptosis. JKAIS, 20, 286-293 (2019)

Kim MJ, Kim WB, Hwang JH, Kim S, Kim BR, Koo KY, Son HJ, Hwang DY, Jung YJ, Lee HS. Characterization of Styela clava tunic after alkaline treatment. J Korean Soc Food Sci Nutr, 45, 690-695 (2016)

Kim YG. Antioxidant. Ryo Moom Gak, Seoul, Korea, p 179-195 (2004)

Kutsuna H, Fujii S, Kitamura K, Komatsu K, Nakano M.
Identification and determination of platelet aggregation inhibitor from safflower (Carthamus tinctorius Linne.). J Pharm Soc Jpn, 108, 1101-1103 (1988)

Lee CB. Picture Book of Korean Plants. In: Safflower, Baekyang Publishers, Seoul, Korea, p 779 (1980)

Lee DH, Hong JH. Antioxidant activities of chlorella extracts and physicochemical characteristics of spray-dried chlorella powders. Korean J Food Preserv, 22, 591-597 (2015)

Lee S, Moon HK, Lee SW, Moon JN, Kim JK. Effects of drying methods on quality characteristics and antioxidative effects of omija (Schizandra chinesis Bailon). Korean J Food Preserv, 21, 341-349 (2014)

Lee SC, Rhim CH, Lee SC. Characteristcis of spray dried polysaccharides for microencapsulation. Korean J Food Sci Technol, 29, 1322-1326 (1997)

Lee SG, Lee EJ, Park WD, Kim JB, Choi SW. Antioxidant and anti-inflammatory activities of extracts from Korean traditional medicinal prescriptions. Korean J Food Sci Technol, 43, 624-632 (2011)

Marshall LJR, Williams JR, Almond MJ, Atkinson SDM, Cook SR, Matthews W, Mortimore JL. Analysis of ochres from clearwell caves: The role of particle size in determining colour. Spectrochim Acta Part A, 61, 233-241 (2005)

Miller NJ, Rice-Evans CA. Factors Influencing the antioxidant activity determined by the $\mathrm{ABTS}^{\circ+}$ radical cation assay. Free Radical Res, 26, 195-199 (1997)

Mishra P, Mishra S, Mahanta CL. Effect of maltodextrin concentration and inlet temperature during spray drying on physicochemical and antioxidant properties of amla (Emblica officinalis) juice powder. Food Bioprod Process, 92, 252-258 (2014)

Nishikimi M, Rao NA, Yagi K. The occurrence of superoxide anion in the reaction of reduced phenazine methosulfate and molecular oxygen. Biochem Biophys Res Commun, 46, 849-854 (1972)

Park CW, Han SY, Lee SH. Spray drying of lignocellulose nanofibril (LCNF) and characterization of spray-dried LCNF. J Korean Wood Sci Technol, 45, 288-296 (2017)

Park JS, Oh JS, Oh JM, Kim YT, Lee JH, Mo JH, Lee HB, Khang G. Sibutramine release behavior from microspheres prepared by spray-dry method. Polymer (Korea), 32, 193-198 (2008) 
Park MJ, Kim SB, Kim SJ, Kim KM, Choi SY, Chang M, Kim GC. Optimization of spray drying conditions of soft persimmon and milk mixture using response surface methodology. Korean J Food Preserv, 24, 957-964 (2017)

Park MY. Study about stability and functionality of safflower colorants. MS Thesis, Jungwon University, Korea, p 1 (2015)

Phillips RD, Chinnan MS, Granch AL, Miller J, Mcwatters $\mathrm{KH}$. Effects of pretreatment on functional and nutritional properties of cowpea meal. J Food Sci, 53, 805-809 (1988)

Re R, Pellegrini N, Proteggnte A, Pannala A, Yang M, Rice-Evans C. Antioxidant acitvity applying an improved ABTS radical cation decolorization assay. Free Radic Biol Med, 26, 1231-1237 (1999)

Rodriguez-Hernandz GR, Gonzales-Garcia R, GrajalesLagunes A, Ruiz-Cabrera MA. Spray-drying of cactus pear juice (Opuntia streptacantha): Effect on the physicochemical properties of powder and reconstituted product. Drying Technol, 23, 955-973 (2005)

Rosenberg M, Kopelman IJ, Talmon Y. Factors affecting retention in spray-drying microencapsulation of volatile materials. J Agric Food Chem, 38, 1288-1294 (1990)

Seo CH, Lee JW, Kim NM, Do JH, Yang JW, Chang KS. Quality characteristics of Korean red ginseng powder with different milling methods. J Korean Soc Food Sci Nutr, 32, 370-374 (2003)

Seo HY. Studies on the enantiodifferentiation and microencapsulation of major volatile flavor of spices. Ph D Thesis, Chosun University, Korea, p 114 (2008)

Shahidi F, Han X. Encapsulation of food ingredients. Crit
Rev Food Sci Nutr, 33, 501-547 (1993)

Shin EJ. Quality characteristics of Bulensia sarmienti powder through spray drying process. MS Thesis, Kyungpook National University, Korea, p 2 (2009)

Song HJ, Jin MH, Lee SH. Effect of ferulic acid isolated from Cnidium officinale on the synthesis of hyaluronic acid. J Soc Cosmet Scientists Korea, 39, 281-288 (2013)

Sormoli ME, Langrish TAG. Spray drying bioactive orangepeel extracts produced by soxhlet extraction: Use of WPI, antioxidant activity and moisture sorption isotherms. LWT-Food Sci Technol, 72, 1-8 (2016)

Tan LH, Chan LW, Heng PWS. Effect of oil loading on microspheres produced by spray drying. J Microencapsul ation, 22, 253-259 (2005)

Yoo DR, Yoo BS. Rheology of rice starch-sucrose composites. Starch-Starke, 57, 254-261 (2005)

Yoon SH, Kim JW. Antioxidative effects of various antioxidants on the soybean oil. J Korean Soc Food Sci Nutr, 17, 19-23 (1988)

Yoon WJ, Lee JA, Kim JY, Oh DJ, Jung YH, Lee WJ, Park SY. Anti-oxidant activities and anti-inflammatory effects on Artemisia scoparia. Kor J Pharmacogn, 37, 235-240 (2006)

You SH, Moon JS. A study on anti-oxidative, anti-inflammatory, and melanin inhibitory effects of Chrysanthemum sibiricum extract. J Korean Oil Chemists Soc, 33, $762-770$ (2016)

Yu MH, Chae IG, Jung YT, Jeong YS, Kim HI, Lee IS. Antioxidative and antimicrobial activities of methanol extract from Rosmarinus officinalis L. and their fractions. J Life Sci, 21, 375-384 (2011) 